\title{
Carcass and Cut Yields and Meat Qualitative Traits of Broilers Fed Diets Containing Probiotics and Prebiotics
}

\section{author(s) \\ Pelicano ERL \\ Souza PA \\ Souza HBA \\ Oba A \\ Boiago MM \\ Zeola NMBL \\ Scatolini AM \\ Bertanha VA \\ Lima TMA}

Departamento de Tecnologia, Faculdade de Ciências Agrárias e Veterinárias - Unesp. Via de Acesso Prof. Paulo Donato Castellane, km 5. Jaboticabal, SP, Brazil

\section{Mail Address}

Elizabete Regina Leone Pelicano
Departamento de Tecnologia
Faculdade de Ciências Agrárias e Veterinárias
- Unesp
Via de Acesso Prof. Paulo Donato Castellane,
km 5
$\begin{array}{ll}\text { 14.884-900. Jaboticabal, SP, Brazil } \\ \text { Phone: } & \text { (55) } 1632092675 \text {, ext. } 245 \\ \text { Fax: } & \text { (55) } 1632092675 \\ \text { E-mail: erlpelicano@yahoo.com.br }\end{array}$

\section{Keywords}

Broilers, carcass yield, cut yield, meat quality, prebiotics, probiotics.

\section{Acknowledgements}

The authors thank Fundação de Amparo à Pesquisa do Estado de São Paulo (FAPESP) for financial support.

\section{ABSTRACT}

This study evaluated the use of different probiotics, prebiotics and symbiotics on the quality of carcasses and meat of broiler chickens. One hundred and eight day-old Cobb male broilers were used $(n=108)$ in a completely randomized design according to a $3 \times 3$ factorial, with 3 probiotics in the diet (no probiotics, probiotics 1, probiotics 2) and 3 prebiotics in the diet (no prebiotics, prebiotics 1, prebiotics 2). There were nine treatments with 4 replicates and 3 birds per replicate. The results showed that the carcass and cut yields, color ( $L^{*}$ - lightness, $a^{*}$ - redness, and $b^{*}$ - yellowness), pH, cooking losses, shearing force and sensory analysis were not affected by the use of different growth promoters at 42 days of age. It was concluded that growth promoters supplemented to the diet did not affect the studied quantitative and qualitative parameters of the carcass and breast meat of broiler chickens.

\section{INTRODUCTION}

In the past decades, the beneficial effects on performance have justified the use of subtherapeutic dosages of antibiotics as additives in animal diets. Nevertheless, there is currently a worldwide decreasing trend in the supplementation of these products to the diets, because of possible contamination of meat products with antibiotic residues, which might be toxic to sensitive individuals, and also because resistant bacteria have emerged. Besides, an increasing number of consumers, particularly in importing countries, have restricted the consumption of poultry originated from birds fed with diets containing antibiotics. In face of these considerations, it becomes evident that studies are needed to evaluate products that might be used as alternatives to these traditional growth promoters, so that there are no decreases in yield or lower meat quality. Therefore, probiotics and prebiotics have been extensively studied worldwide as a possible alternative to the use of antibiotics (Pelicano et al., 2002).

Probiotics are classified as safe and called "generally regarded as safe substances" (GRAS) by the Food and Drug Administration (FDA, 1989). The concept behind their use is that the addition of beneficial microorganisms improves the balance of the intestinal microflora (Goldin, 1998). Prebiotics, on the other hand, are defined as non-digestible ingredients that are beneficial to the host because they selectively stimulate the growth and/or the activity of a limited number of intestinal bacteria (Gibson \& Roberfroid, 1995).

Many studies have confirmed the viability of using such products to improve animal production indexes (Besnard et al., 2000; Maiorka et al., 2001 and Pelicano et al., 2004). Nevertheless, the utilization of these additives must be better evaluated not only as growth promoters, but also based on their effect on the production of prime cuts and high-quality meat. 
Pelicano ERL, Souza PA, Souza HBA,

Oba A, Boiago MM, Zeola NMBL,

Scatolini AM, Bertanha VA, Lima

TMA

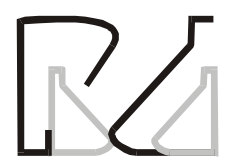

Carcass and Cut Yields and Meat Qualitative Traits of Broilers Fed Diets Containing Probiotics and Prebiotics
Many questions have been raised about the use of such additives in relation to meat quality. In fact, many unclear results exist on this issue. Some authors consider that feeding such products has been advantageous as a means to improve meat quality and carcass quality (Burkett et al., 1977; Jensen \& Jensen, 1992; Maruta, 1993; Stanley et al., 1996; Jin et al., 1998 and Santos et al., 2002), whereas others have described discordant results (Owings et al., 1990, Loddi et al., 2000, Quadros et al., 2001, Vargas Jr. et al, 2002 and Pelicano et al., 2003).

The present study evaluated the effect of different probiotics, prebiotics and their association on carcass and cut yields, as well as some qualitative characteristics of the breast meat in broiler chickens.

\section{MATERIAL AND METHODS}

The trial and bird slaughter were carried out at the poultry facilities of Faculdade de Ciências Agrárias e Veterinárias - FCAV/UNESP, Jaboticabal, São Paulo, Brazil. Laboratory analyses were performed in Laboratório de Tecnologia e Processamento de Produtos de Origem Animal (TPPOA) from the Departamento de Tecnologia, FCAV/UNESP.

The experiment was carried out using 1,260 male chicks from Cobb strain. The birds were housed in an experimental poultry house with 36 pens (35 birds/pen) measuring $3.20 \mathrm{~m} \times 1.46 \mathrm{~m}$. Bird density was 8 birds/ $\mathrm{m}^{2}$. At the end of the experimental period (42 days of age), three birds per replicate were slaughtered to evaluate carcass and cut yields (108 birds). Furthermore, two birds per replicate were slaughtered to assess color, $\mathrm{pH}$, cooking loss and shearing force (72 birds) and two birds per treatment were slaughtered for sensory analysis (18 birds).

The data of carcass and cut yields, color, pH, cooking losses and shearing force were analyzed by analysis of variance using a completely randomized design in a $3 \times 3$ factorial arrangement, with 3 probiotics sources (no probiotics, pro 1, pro 2) and 3 prebiotics sources (no prebiotics, pre 1, pre 2), in a total of 9 treatments and 4 replicates with 3 birds (for carcass and cut yields) and 2 birds (for meat qualitative analyses). The data of sensory analysis were submitted to analysis of variance in a completely randomized design. Statistical analysis was performed considering 3 treatments to compare within probiotics sources (no probiotics, pro 1, pro 2) and within prebiotics sources (no prebiotics, pre 1, pre 2 ), whereas 5 treatments were considered to evaluate the association between the products - symbiotics (no prebiotics or probiotics, Pro $1+$ Pre 1, Pro $1+$ Pre 2, Pro $2+$ Pre 1, Pro $2+$ Pre 2)

The analyses of variance were performed using Estat 2.0 (1992) and the contrasts between treatment means were evaluated by the Tukey's test at a significance level of $5 \%(p<0.05)$.

The treatments were as follows: 1 - Control (no growth promoters); 2 - Bacillus subtilis-based probiotics added to the diet at $150 \mathrm{~g} / \mathrm{ton}$ from 1 to 42 days of age (Pro 1); 3 - Probiotics based on Lactobacillus acidophilus and casei, Streptococcus lactis and faecium, Bifidobacterium bifidum and Aspergillus oryzae added to the diet at $1 \mathrm{~kg} /$ ton from 1 to 42 days of age (Pro 2); 4 - Prebiotics based on phosphorylated mannanoligosaccharide (MOS) and organic acidifier added to the diet at $2 \mathrm{~kg} /$ ton from 1 to 21 days and $1.5 \mathrm{~kg} /$ ton from 22 to 42 days of age (Pre 1); 5 - MOSbased prebiotics added to the diet at $1 \mathrm{~kg} /$ ton from 1 to 21 days and $0.5 \mathrm{~kg} /$ ton from 22 to 42 days of age (Pre 2); 6 - Pro $1+$ Pre 1; 7 - Pro 1 + Pre 2; 8 - Pro $2+$ Pre 1; and 9 - Pro 2 + Pre 2.

The birds were fed water and feed ad libitum throughout the rearing period, which was divided into three phases. The birds were given starter diets with $3000 \mathrm{kcal} \mathrm{ME} / \mathrm{kg}, 21.4 \%$ crude protein, $1.263 \%$ Lysine, $0.561 \%$ Methionine, $0.960 \% \mathrm{Ca}$ and $0.450 \%$ available $P$ in the initial phase (1-21 days). Grower diets (22-35 days) contained $3100 \mathrm{kcal} \mathrm{ME} / \mathrm{kg}, 19.3 \%$ crude protein, $1.156 \%$ Lysine, $0.514 \%$ Methionine, $0.874 \% \mathrm{Ca}$ and $0.406 \%$ available $P$, whereas the final diets $(36-42$ days) had $3200 \mathrm{kcal} \mathrm{ME} / \mathrm{kg}, 18 \%$ crude protein, $1.040 \%$ Lysine, $0.445 \%$ Methionine, $0.800 \% \mathrm{Ca}$ and $0.365 \%$ available $P$. Other levels were as recommended by Rostagno et al. (2000).

At 42 days of age, broilers were slaughtered and processed according to standard slaughter procedures: stunning (7 s), bleeding (2.0 min), scalding for $2.5 \mathrm{~min}$ at $54^{\circ} \mathrm{C}$, defeathering, eviscerating, pre-chilling in water at $20^{\circ} \mathrm{C}$ for $20 \mathrm{~min}$, chilling at $4^{\circ} \mathrm{C}$ for $25 \mathrm{~min}$, and dripping for $3 \mathrm{~min}$. After dripping carcasses were packaged in plastic bags and placed on ice until quantitative and qualitative analyses.

To evaluate carcass and cut yields, the birds were identified at the end of the trial, individually weighed and housed in pens. They were fasted for approximately 6 hours, but were given water during this period. In the slaughterhouse, the birds were re-weighed before being killed. After the standard slaughter procedures and dripping, carcasses were weighed without feet, head and neck, and the cuts were performed to evaluate the yield of legs, breast, back, wings and abdominal fat (\%). 
Pelicano ERL, Souza PA, Souza HBA,

Oba A, Boiago MM, Zeola NMBL,

Scatolini AM, Bertanha VA, Lima

TMA

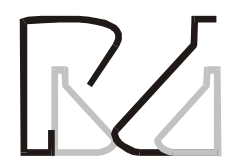

Carcass and Cut Yields and Meat Qualitative Traits of Broilers Fed Diets Containing Probiotics and Prebiotics
Color measurements were taken using a Minolta Chroma Meter CR-200. It was evaluated the $L^{*}$, $a^{*}$, $b^{*}$ measurements from CIELab system, where $L^{*}$ is the chrome associated to meat lightness, $a^{*}$ is the chrome that ranges between green (-) to red (+) and $b^{*}$ is the chrome that ranges between blue (-) and yellow (+). The readings were performed 5 hours after slaughter at the TPPOA laboratory. The mean color response of $L^{*}, a^{*}, b^{*}$ of the Pectoralis major muscle was calculated using five readings in different positions.

Meat $\mathrm{pH}$ levels were determined using a digital pHmeter (Testo). The electrode was directly introduced into the breast meat. pH measurements were also performed 5 hours after slaughter in the chilled carcasses at the TPPOA laboratory.

Cooking losses $(\mathrm{CL})$ were determined 5 hours after slaughter, according to the methodology proposed by Cason et al. (1997). Raw breast meat samples were weighed and packaged, then steam-cooked in a water-bath at $85^{\circ} \mathrm{C}$ for 30 minutes. After this procedure, the samples were cooled at room temperature and re-weighed. CL were calculated as the difference between the initial and the final weight. The samples used to determine CL were the same used to evaluate shearing force.

Tenderness was objectively determined using a Texture Analyzer TA-XT2i coupled to a WarnerBratzler probe. The cooked breast muscle samples used in this procedure were the same used to determine $\mathrm{CL}$. After all samples were at room temperature, they were cut into slices of approximately $1.5 \mathrm{~cm}$ in width and placed perpendicularly to the Warner-Bratzler blade. The maximum force needed to cut the slices was then determined (kgf).

The sensory analysis of breast meat was evaluated 5 hours after slaughter. Samples were previously salted with $1.5 \%(\mathrm{w} / \mathrm{W})$ of salt and cooked in a pre-heated oven $\left(170^{\circ} \mathrm{C}\right)$ until the internal temperature reached $75^{\circ} \mathrm{C}$. After the size and temperature of the samples were similar, they were tasted by panelists inside individual sensory booths. The samples were provided into disposable trays codified with 3 digits. The sensory analyses were made by 20 panelists, using an unstructured hedonic scale for the acceptance test (9 $\mathrm{cm})$, ranging from "disliked extremely" to "liked extremely" based on the following attributes: flavor, tenderness and global impression.

\section{RESULTS AND DISCUSSION}

Table 1 shows the mean body weights before slaughter and the carcass and cut yields of 42-day-old broiler chickens fed diets containing probiotics and prebiotics. Pre-slaughter body weight was greater $(p<0.05)$ in the birds fed probiotics based on a bacterial pool, whereas lower weight was observed in the birds fed single-culture probiotics in the diet. There were no differences in weight due to the use of different prebiotics. Nevertheless, no differences were seen in carcass yield due to the use of probiotics and prebiotics, and these results were similar to findings reported by Maiorka et al. (2001), Moreira et al. (2001) and Vargas Jr. et al. (2002).

The cut yields were also not affected ( $p>0.05)$ by the different additives that were used, similarly to the

\begin{tabular}{|c|c|c|c|c|c|c|c|}
\hline \multirow{2}{*}{$\begin{array}{l}\text { Evaluated } \\
\text { Parameter }\end{array}$} & \multicolumn{7}{|c|}{ Yield (\%) } \\
\hline & Pre-slaughter (g) & Carcass & Legs & Breast & Back & Wings & Fat \\
\hline \multicolumn{8}{|c|}{ Probiotic in diet (PRO) } \\
\hline Control & 2351 ab & 74.40 & 32.97 & 34.81 & 19.85 & 11.19 & 1.18 \\
\hline Probiotic $1^{(1)}$ & $2314^{b}$ & 74.05 & 33.12 & 34.51 & 19.74 & 11.37 & 1.26 \\
\hline Probiotic $2^{(2)}$ & $2426^{a}$ & 75.00 & 32.76 & 35.14 & 19.74 & 11.11 & 1.25 \\
\hline \multicolumn{8}{|c|}{ Prebiotic in diet (PRE) } \\
\hline Control & 2347 & 74.48 & 32.82 & 34.67 & 19.95 & 11.23 & 1.33 \\
\hline Prebiotic $1^{(3)}$ & 2377 & 74.39 & 33.28 & 34.79 & 19.50 & 11.17 & 1.26 \\
\hline Prebiotic $2^{(4)}$ & 2367 & 74.58 & 32.74 & 35.00 & 19.87 & 11.27 & 1.12 \\
\hline \multicolumn{8}{|c|}{ F Test } \\
\hline Probiotic & $3.95 *$ & $1.82 \mathrm{~ns}$ & $0.70 \mathrm{~ns}$ & $1.62 \mathrm{~ns}$ & $0.14 \mathrm{~ns}$ & $2.18 \mathrm{~ns}$ & $0.35 \mathrm{~ns}$ \\
\hline Prebiotic & $0.28 \mathrm{~ns}$ & $0.08 \mathrm{~ns}$ & $1.76 \mathrm{~ns}$ & $0.46 \mathrm{~ns}$ & $2.14 \mathrm{~ns}$ & $0.29 \mathrm{~ns}$ & $2.05 \mathrm{~ns}$ \\
\hline PRO $\times$ PRE & $1.75 \mathrm{~ns}$ & $0.84 \mathrm{~ns}$ & $0.60 \mathrm{~ns}$ & $1.57 \mathrm{~ns}$ & $1.01 \mathrm{~ns}$ & $1.41 \mathrm{~ns}$ & $0.49 \mathrm{~ns}$ \\
\hline CV (\%) & 7.29 & 1.63 & 2.30 & 2.46 & 2.89 & 2.83 & 20.87 \\
\hline
\end{tabular}

a, b - Within the same factor, means followed by similar letters in the column are similar ( $p>0.05)$ by Tukey's Test. Test F: ns, non-significant; * $\mathrm{p}<0.05$. CV - Coefficient of Variation. (1) Probiotics based on Bacillus subtilis added to the diet throughout the experimental period, (2) Probiotics based on Lactobacillus acidophilus and casei, Streptococcus lactis and faecium, Bifidobacterium bifidum and Aspergillus oryzae added to the diet throughout the experimental period, (3) Prebiotics based on MOS and organic acidifier added to the diet throughout the experimental period, (4) Prebiotics based on MOS added to the diet throughout the experimental period. 
Pelicano ERL, Souza PA, Souza HBA,

Oba A, Boiago MM, Zeola NMBL, Scatolini AM, Bertanha VA, Lima TMA
Carcass and Cut Yields and Meat Qualitative Traits of Broilers Fed Diets Containing Probiotics and Prebiotics results reported by Henrique et al. (1998), Loddi et al. (2000) and Pelícia et al. (2003). On the other hand, Corrêa et al. (2000), Santos et al. (2002) and Pelicano et al. (2003) evaluated different probiotics and reported leg yields significantly higher when the products were added to the diet. Therefore, it is suggested that such promoters might be used in broiler diets, since they do not interfere, or interfere positively, on the yield of the most commercialized edible cuts (breast, legs and wings).

The color parameters lightness ( $L^{*}$ value), redness ( $a$ * value) and yellowness ( $b$ * value) of the breast meat were not different ( $p>0.05)$ between the different treatments or between these and the control treatment 5 hours after slaughter (Table 2). According to Contreras (2001), broiler meat color in natura is important because consumers associate the color with freshness and good quality. Therefore, the different additives might be used since they did not affect meat color, which is an extremely important parameter that is related to the choice made by the consumer. Pelicano et al. (2003) added probiotics both to the drinking water and to the diet of broiler chickens and observed $L^{*}$ values significantly smaller at 45 minutes and 5 hours after slaughter. The values reported by Pelicano et al. (2003) for $L *, a *$ and $b$ * were, respectively, from 49.95 to 48.10; from 4.80 to 4.24 and from 4.98 to 3.80 , which are considerably higher than the values found in the present study.

\begin{tabular}{|c|c|c|c|c|}
\hline \multirow{2}{*}{$\begin{array}{l}\text { Evaluated } \\
\text { Parameters }\end{array}$} & \multicolumn{3}{|c|}{ Color } & \multirow[t]{2}{*}{$\mathrm{pH}$} \\
\hline & $L^{*}$ value & $a^{*}$ value & b* value & \\
\hline \multicolumn{5}{|c|}{ Probiotic in diet (PRO) } \\
\hline Control & 45.25 & 3.88 & 2.87 & 5.82 \\
\hline Probiotic $1^{(1)}$ & 46.37 & 3.88 & 3.35 & 5.82 \\
\hline Probiotic $2^{(2)}$ & 45.69 & 3.80 & 3.36 & 5.74 \\
\hline \multicolumn{5}{|c|}{ Prebiotic in diet (PRE) } \\
\hline Control & 46.21 & 3.94 & 2.91 & 5.79 \\
\hline Prebiotic $1^{(3)}$ & 44.87 & 3.83 & 3.12 & 5.80 \\
\hline Prebiotic $2^{(4)}$ & 46.23 & 3.80 & 3.55 & 5.80 \\
\hline \multicolumn{5}{|c|}{$\mathrm{F}$ test } \\
\hline Probiotic & $1.41 \mathrm{~ns}$ & $0.08 \mathrm{~ns}$ & $1.40 \mathrm{~ns}$ & $3.34 \mathrm{~ns}$ \\
\hline Prebiotic & $2.67 \mathrm{~ns}$ & $0.21 \mathrm{~ns}$ & $1.92 \mathrm{~ns}$ & 0.07 ns \\
\hline PRO $\times$ PRE & $0.29 \mathrm{~ns}$ & $0.76 \mathrm{~ns}$ & $0.38 \mathrm{~ns}$ & $0.67 \mathrm{~ns}$ \\
\hline CV $(\%)$ & 3.61 & 14.10 & 25.63 & 1.53 \\
\hline
\end{tabular}

Test F: ns, non-significant. CV - Coefficient of Variation. (1) Probiotics based on Bacillus subtilis added to the diet throughout the experimental period. (2) Probiotics based on Lactobacillus acidophilus and casei, Streptococcus lactis and faecium, Bifidobacterium bifidum and Aspergillus oryzae added to the diet throughout the experimental period. (3) Prebiotics based on MOS and organic acidifier added to the diet throughout the experimental period. (4)Prebiotics based on MOS added to the diet throughout the experimental period.
Breast meat $\mathrm{pH}$ values measured 5 hours after slaughter were also not affected $(p>0.05)$ by the presence of probiotics and/or prebiotics. Similar results have been reported by Quadros et al. (2001), who did not find significant differences in $\mathrm{pH}$ values measured 45 min and 24 hours after slaughter in pork from swine fed diets containing growth promoters.

$\mathrm{pH}$ values were stable and ranged between 5.82 and 5.74 independent of diet supplementation with additives. According to Pearson (1994), biochemical processes, such as $\mathrm{pH}$ changes, should occur so that the animal muscle is converted into meat. $\mathrm{pH}$ values in the muscle of live animals is approximately 7.4. According to Jones \& Grey (1989) and Sams \& Mills (1993), at the end of the post-mortem process, the normal $\mathrm{pH}$ range lies between 5.6 and 5.8 or 5.78 to 5.86 , respectively. Therefore, the data of the present study are within the values reported in the literature independent of the use of probiotics and/or prebiotics.

There were no significant differences for the values of cooking loss $(\mathrm{CL})$ and shearing force (SF) values in the breast meat when different additives were used (Table 3). These findings partially corroborate the results reported by Quadros et al. (2001) and Pelicano et al. (2003), who found no differences in SF and CL in the meat of swine and chicken fed with probiotics, respectively. Besides, Pelícia et al. (2004) also reported no differences in these qualitative characteristics due to the administration of probiotics and prebiotics to free-range broiler chickens.

\begin{tabular}{|c|c|c|}
\hline \multicolumn{3}{|c|}{$\begin{array}{l}\text { Table } 3 \text { - Cooking losses }(\mathrm{CL}) \text { and shearing force (SF) of brea } \\
\text { meat in broilers fed diets containing probiotics and prebiotics } \\
\text { hours after slaughter. }\end{array}$} \\
\hline Evaluated & & \\
\hline Parameters & CL (\%) & SF (kgf) \\
\hline \multicolumn{3}{|c|}{ Probiotic in diet (PRO) } \\
\hline Control & 17.40 & 4.09 \\
\hline Probiotic $1^{(1)}$ & 18.15 & 4.08 \\
\hline Probiotic $2^{(2)}$ & 16.75 & 3.88 \\
\hline \multicolumn{3}{|c|}{ Prebiotic in diet (PRE) } \\
\hline Control & 17.43 & 4.18 \\
\hline Prebiotic $1^{(3)}$ & 17.73 & 3.84 \\
\hline Prebiotic $2^{(4)}$ & 17.15 & 4.03 \\
\hline \multicolumn{3}{|c|}{$F$ test } \\
\hline Probiotic & 0.79 ns & $0.30 \mathrm{~ns}$ \\
\hline Prebiotic & $0.14 \mathrm{~ns}$ & $0.59 \mathrm{~ns}$ \\
\hline PRO $\times$ PRE & $1.94 \mathrm{~ns}$ & $1.07 \mathrm{~ns}$ \\
\hline CV (\%) & 15.61 & 19.13 \\
\hline
\end{tabular}

Test F: ns, non-significant. CV - Coefficient of Variation. (1) Probiotics based on Bacillus subtilis added to the diet throughout the experimental period. (2) Probiotics based on Lactobacillus acidophilus and casei, Streptococcus lactis and faecium, Bifidobacterium bifidum and Aspergillus oryzae added to the diet throughout the experimental period. (3) Prebiotics based on MOS and organic acidifier added to the diet throughout the experimental period. (4) Prebiotics based on MOS added to the diet throughout the experimental period. 
Pelicano ERL, Souza PA, Souza HBA,

Oba A, Boiago MM, Zeola NMBL, Scatolini AM, Bertanha VA, Lima TMA Broilers Fed Diets Containing Probiotics and Prebiotics
According to Lyon \& Lyon (1990), SF values up to $7.5 \mathrm{kgf}$ might be considered tender; nevertheless, Simpson \& Goodwin (1974) suggested values of up to $8 \mathrm{kgf}$. In regard to these reference values for SF, it can be inferred that the use of probiotics and prebiotics in the present study had no effect on breast meat tenderness, since the values ranged between 3.88 and 4.08 and between 3.84 and $4.03 \mathrm{kgf}$, respectively. Together with water holding capacity, CL and SF are quality parameters intimately related with the process of meat tenderness, which is a determining qualitative factor and one of the most important sensory characteristics of the meat (Koohmaraie et al., 1990). It is worth noting that water loss reduces the nutritional value of meat, since nutrients might be removed together with the exsudate, resulting in less tender meat. Nevertheless, tenderness was not affect in the present study.

There were no statistical differences ( $p>0.05)$ in the sensory analysis of the evaluated characteristics (flavor, tenderness and global impression) due to the different products (Tables 4 and 5). The results are not in accordance with the findings of previous studies, in which meat flavor was positively affected by the addition of Bacillus sp. spores (Jensen \& Jensen, 1992) and Lactobacillus sp. spores (Pelicano et al., 2003) during refrigeration. Loddi et al. (2000) observed no effect of growth promoters on the sensory analysis of breast meat. Nevertheless, when leg meat was evaluated, there was a significant difference in the characteristics strange aroma, strange flavor and preference between the treatments fed with probiotics + antibiotics and the treatment fed only with antibiotics, which was given the lowest scores by the panelists. Pelícia et al. (2004) evaluated the influence of biological promoters (probiotics, prebiotics, coccidiosis vaccines and anticoccidiostats) on the sensory analysis of breast meat of free-range broiler chickens. The authors observed that the different promoters had no influence on the characteristics "tenderness" and "general aspect" of the breast meat.

\section{CONCLUSION}

It was concluded that the addition of growth promoters did not influence the qualitative and quantitative parameters of carcass and breast meat of broiler chickens.

\begin{tabular}{|c|c|c|c|}
\hline $\begin{array}{l}\text { Evaluated } \\
\text { Parameters }\end{array}$ & Flavor $^{(5)}$ & Tenderness $^{(5)}$ & $\begin{array}{c}\text { Global } \\
\text { Impression }^{(5)}\end{array}$ \\
\hline \multicolumn{4}{|c|}{ Probiotic in diet (PRO) } \\
\hline Control & 6.01 & 5.61 & 6.00 \\
\hline Probiotic $1^{(1)}$ & 6.34 & 6.14 & 6.38 \\
\hline Probiotic $2^{(2)}$ & 5.37 & 5.28 & 5.35 \\
\hline SEM & 1.43 & 1.79 & 1.53 \\
\hline CV (\%) & 24.23 & 31.48 & 25.99 \\
\hline \multicolumn{4}{|c|}{ Prebiotic in diet (PRE) } \\
\hline Control & 6.30 & 5.95 & 6.12 \\
\hline Prebiotic $1^{(3)}$ & 5.88 & 6.15 & 5.97 \\
\hline Prebiotic $2^{(4)}$ & 5.65 & 5.22 & 5.70 \\
\hline SEM & 1.61 & 1.78 & 1.62 \\
\hline CV (\%) & 27.10 & 30.78 & 27.36 \\
\hline
\end{tabular}

SEM - Standard Error of the Mean, CV - Coefficient of Variation (1) - Probiotics based on Bacillus subtilis added to the diet throughout the experimental period, (2) - Probiotics based on Lactobacillus acidophilus and casei, Streptococcus lactis and faecium, Bifidobacterium bifidum and Aspergillus oryzae added to the diet throughout the experimental period, (3) - Prebiotics based on MOS and organic acidifier added to the diet throughout the experimental period, (4) - Prebiotics based on MOS added to the diet throughout the experimental period, (5) - Structural scale varying from 0 to 9 $\mathrm{cm}$.

\begin{tabular}{|c|c|c|c|}
\hline $\begin{array}{l}\text { Evaluated } \\
\text { Parameters }\end{array}$ & Flavor ${ }^{(5)}$ & Tenderness ${ }^{(5)}$ & $\begin{array}{c}\text { Global } \\
\text { Impression }^{(5)}\end{array}$ \\
\hline \multicolumn{4}{|c|}{${ }^{(*)}$ Probiotic in diet (PRO) } \\
\hline Control & 5.85 & 6.17 & 5.93 \\
\hline Pro 1 + Pre $1^{(1)}$ & 5.32 & 6.16 & 5.81 \\
\hline Pro 1 + Pre $2^{(2)}$ & 5.50 & 4.89 & 5.34 \\
\hline Pro 2 + Pre $1^{(3)}$ & 5.86 & 5.36 & 5.54 \\
\hline Pro $2+$ Pre $2^{(4)}$ & 5.72 & 5.85 & 5.76 \\
\hline SEM & 1.78 & 1.84 & 1.89 \\
\hline CV $(\%)$ & 31.42 & 32.28 & 33.33 \\
\hline
\end{tabular}

SEM - Standard Error of the Mean, CV - Coefficient of Variation. (1) - Probiotics based on Bacillus subtilis added to the diet throughout the experimental period + Prebiotics based on MOS and organic acidifier added to the diet throughout the experimental period. (2) Probiotics based on Bacillus subtilis added to the diet throughout the experimental period + Prebiotics based on MOS added to the diet throughout the experimental period. (3) - Probiotics based on Lactobacillus acidophilus and casei, Streptococcus lactis and faecium, Bifidobacterium bifidum and Aspergillus oryzae added to the diet throughout the experimental period + Prebiotics based on MOS and organic acidifier added to the diet throughout the experimental period. (4) Probiotics based on Lactobacillus acidophilus and casei, Streptococcus lactis and faecium, Bifidobacterium bifidum and Aspergillus oryzae added to the diet throughout the experimental period + Prebiotics based on MOS added to the diet throughout the experimental period. (5) Structural scale varying from 0 to $9 \mathrm{~cm}$. (*) Probiotic and prebiotic in diet. 


\section{REFERENCES}

Besnard J, Auclair E, Larbier M. Effect of yeast supplementation on productive parameters of turkeys. In: World's Poultry Science Congres; 2000; Montreal, CA: WPSA; 2000.

Burkett RF, Thayer RH, Morrison RD. Supplementing market broiler diets with Lactobacillus and live yeast cultures. Stillwater: Oklahoma State University; 1977.

Cason JA, Lyon CE, Papa C. Effect of muscle opposition during rigor on development of broiler breast meat tenderness. Poultry Science 1997; 76:785-787.

Contreras CJC. Qualidade de carcaça e carne de aves. In: Anais do $1^{\circ}$ Congresso Brasileiro de Ciência e Tecnologia de Carnes; 2001; São Pedro. p.160-178.

Corrêa GSS, Gomes AVC, Corrêa AB, Salles AS. Desempenho de frangos de corte alimentados com diferentes promotores de crescimento. In: Anais da $37^{a}$ Reunião Anual da Sociedade Brasileira de Zootecnia; 2000; Viçosa: SBZ, 2000. p. 37.

Estat 2.0 Sistema de Análise Estatística. Jaboticabal: Polo Computacional - Departamento de Ciências Exatas - UNESP; 1992.

Food and Drug Administration. Compliance policy guide n7126.41, 1989.

Gibson GR, Roberfroid MB. Dietary modulation of the human colonic microbiota: introducing the concept of prebiotics. Journal of Nutrition 1995; 125:1401-1412.

Goldin BR. Health benefits of probiotics. British Journal of Nutrition 1998; 80 (2):203-207

Henrique APF, Faria DE, Franzolin R, Ito DT. Efeito de ácido orgânico, probiótico e antibiótico sobre o desempenho e rendimento de carcaça de frangos de corte. In: Anais da $35^{a}$ Reunião Anual da Sociedade Brasileira de Zootecnia; 1998; Botucatu: SBZ, p.300-302.

Jensen JF, Jensen MM. The effect of using growth promoting Bacillus strains in poultry feed. In: 18 World's Poultry Congress; 1992; Amsterdam: WPSA, v.3, 398-402.

Jin LZ, Ho YM, Abdullah N, Jalaludin S. Growth performance, intestinal microbial populations, and serum cholesterol of broilers fed diets containing Lactobacillus cultures. Poultry Science 1998; 77:1259-1265.

Jones JM, Grey TC. Influence of processing on product quality and yield. In: Mead GC, editor. Processing of poultry. New York: Elsevier Applied Science, 1989, p. 127-130.

Koohmaraie M, Whipple G, Crousse L. Acceleration of post mortem tenderization in lamb and Brahman-cross beef carcasses through infusion of calcium chloride. Journal of Animal Science 1990; 68 (5):1278-1283.

Lyon CE, Lyon BG. The relationship of objective: shear value and sensory vests to changes in tenderness of broiler breast meat. Poultry Science 1990; 69(8):1420-1427.
Loddi MM, Gonzales E, Takita TS, Mendes AAM, Roça RO. Uso de probiótico e antibiótico sobre o desempenho, rendimento e qualidade da carcaça de frangos de corte. Revista Brasileira de Zootecnia 2000; 29(4):1124-1131.

Maiorka A, Santin E, Sugeta SM, Almeida JC, Macari M. Utilização de prebióticos, probióticos ou simbióticos em dietas para frangos. Revista Brasileira de Ciência Avícola 2001; 3(1):75-82.

Maruta K. Probióticos e seus benefícios. In: Conferência Apinco 1993 de Ciência e Tecnologia Avícolas; 1993; Santos, BR. p.203219

Moreira J, Mendes AA, Garcia EA, Garcia RG, Almeida ICL, Jr. JCG. Efeito do uso do probiótico sobre o desempenho e rendimento de carcaça em frangos de corte. In: Anais da $38^{a}$ Reunião Anual da Sociedade Brasileira de Zootecnia; 2001; Piracicaba:SBZ, p.852854

Owings WJ, Reynoldas DL, Hasiak RJ, Ferket PR. Influence of dietary supplementation with Streptococcus faecium M - 74 on broiler body weight, feed conversion, carcass characteristics, and intestinal microbial colonization. Poultry Science 1990; 69:1257-1264.

Pearson AM. La fucion muscular y los cambios post mortem. In: Price JR, Scheweigert BS. Ciencia de la carne y de los productos carnicos. $2^{\text {nd }}$ ed. Zaragoza: Acribia; 1994. 273p.

Pelicano ERL, Souza PA, Souza HBA. Prebióticos e Probióticos na nutrição de aves. Ciências Agrárias e da Saúde 2002; 2 (1): 59-64.

Pelicano ERL, Souza PA, Souza HBA, Oba A, Norkus EA, Kodawara LM, Lima TMA. Effect of different probiotics on broiler carcass and meat quality. Revista Brasileira de Ciência Avícola 2003; 5 (3):207214.

Pelicano ERL, Souza PA, Souza HBA, Leonel FR, Zeola NMBL, Boiago MM. Productive traits of broiler chickens fed diets containing different growth promoters. Revista Brasileira de Ciência Avícola 2004; 6 (3):177-182.

Pelicia K, Mendes AAM, Saldanha ESPB, Pizzolante CC, Takahashi SE, Moreira J, Garcia RG, Oliveira RP, Quintero RR, Almeida ICL. Efeito de antibiótico, prebiótico e probiótico sobre o desempenho, rendimento de carcaça e desenvolvimento do intestino de frangos de corte tipo colonial. In: Anais da 40a Reunião Anual da Sociedade Brasileira de Zootecnia; 2003; Santa Maria: SBZ, 2003. CD-ROM.

Pelicia K, Mendes AAM, Saldanha ESPB, Pizzolante CC, Takahashi SE, Garcia RG, Paz ICLA, Quintero RR. Utilização de promotores biológicos para frangos de corte tipo colonial. Revista Brasileira de Ciência Avícola 2004; (supl 6): 21.

Quadros ARB, Kiefer C, Ribeiro NLC, Zink LA. Características qualitativas da carne de suínos alimentados com rações contendo ou não probióticos. In: Anais da $38^{a}$ Reunião Anual da Sociedade Brasileira de Zootecnia; 2001; Piracicaba: SBZ; 2001. p.794-795.

Rostagno HS, Albino LFT, Donzele JL, Gomes PC, Ferreira AS, Oliveira RF, Lopes DC. Tabelas brasileiras para aves e suínos: composição de alimentos e exigências nutricionais. Viçosa:Horacio Rostagno; 2000. $141 p$. 
Pelicano ERL, Souza PA, Souza HBA,

Oba A, Boiago MM, Zeola NMBL,

Scatolini AM, Bertanha VA, Lima TMA

Sams AR, Mills KA. The effect of feed withdrawal duration on the responsiveness of broiler pectoralis to rigor mortis acceleration. Poultry Science 1993; 72(9):1789-1796.

Santos EC, Teixeira AS, Rodrigues PB, Bertechini AG, Freitas RTF, Dias ES, Torres DM, Santos AV, Giacometi R. Uso de aditivos beneficiadores de crescimento sobre o rendimento de carcaça de frangos de corte. In: Anais da 39a Reunião Anual da Sociedade Brasileira de Zootecnia; 2002; Recife: SBZ, 2002. CD-ROM.

Simpson MD, Goodwin TL. Comparison between shear values and test panel scores for predicting tenderness of broilers. Poultry Science 1974; 53(6):2042-2046.

Stanley VG, Gray C, Chukwu H. Effects of lactose and Bio-mos in dietary application on growth and total coliform bacteria reduction in broiler chicks. Poultry Science 1996; 75(suppl. 1):61.

Vargas Jr. JG, Toledo RS, Albino LFT, Rostagno HS, Oliveira JE, Carvalho DCO. Características de carcaça de frango de corte, submetidos a rações contendo probióticos, prebióticos e antibióticos. In: Anais da 39a Reunião Anual da Sociedade Brasileira de Zootecnia; 2002; Recife: SBZ, 2002. CD-ROM. 